\title{
“AN UNUSUALLY ACTIVE MARKET FOR CALAMUS": \\ Whitman, Vanity Fair, and the Fate of Humor in a Time of War, 1860-1863
}

\author{
ROBERT J. SCHOLNICK
}

ON MARCH 9, 1861, the New York humor magazine Vanity Fair unhesitatingly addressed what it identified as "The Great Literary Question of the Day": "What will Walt. Whitman's Leaves of Grass be when they are dried, and posterity has raked 'em-Hey?"1 Vanity Fair pokes fun at Whitman - his Leaves after all might turn out to be but fodder for bovines. Yet, it paid him the great compliment of recognizing that succeeding generations would continue to be chewing on Leaves of Grass. But lest the editors be held liable, Vanity Fair had warned one and all that reading Whitman's poetry carried risk. Some nine months earlier, on September 15, 1860, under the title "Curious if True," the weekly reported that " A young lady who graduated recently at an institute in Virginia, has been committed to the Insane Asylum at Raleigh. Her friends attribute her mental aberration to the reading of Milton's Paradise Lost.-Exchange.' Good gracious-what would have become of her had she had read - say for instance Walt Whitman, or one of Adah Isaac Menken's high pressurisms?"2 Given the friendship between Whitman and the notorious actress and poet Menken, fellow habitués of Pfaff's, the bohemian café at 647 Broadway much favored by Vanity Fair editors and writers, the comparison is apt. ${ }^{3}$

During its short existence-from December 31, 1859 to July, 1863-Vanity Fair published at least twenty-two references to Whitman, only eight of which are listed in the standard bibliography. ${ }^{4}$ That Vanity Fair, described by Frank Luther Mott as "this best of the early comic papers," gave such extensive, positive, and revealing attention to Whitman is one indication of the way that it saw its function as an exponent of worldly, adult New York humor: to poke fun at the pomposity, hypocrisy, and cant of the politicians, preachers, and literary highbrows who controlled public discourse. ${ }^{5}$ Both Whitman and his fellow Pfaffians were determined to resist a culture that sought to limit all sexual expression to the marriage bed and then only for purposes of procreation. In Whitman the weekly had a powerful symbol of liberation in its several 
forms, someone quite willing to lead his readers "In Paths Untrodden," to use the title of the poem he placed first in the "Calamus" sequence, which he added to Leaves of Grass in 1860. Not surprisingly, certain of the references to Whitman in Vanity Fair refer to his identity as a gay poet.

No one could charge those who wrote for Vanity Fair with not knowing Whitman's work or, for that matter, understanding the influences that had shaped him as the "originator of the grass school of poetry," as it described him in May $1862 .{ }^{6}$ On December 15,1860 , in a piece on "The Aesthetics of the Boot," the writer, who signed himself Aldi Borondi Fosca Phorniosticus, testified that he too had "travelled through the Wilt Waterman, the Weller and Fowls, and the R.A.F. Waldersonian Schools" of poetry, phrenology, and philosophy. Phorniosticus, whom I have not identified, assumed a knowledge on the part of the reader of the phrenological publishing firm of Fowler and Wells, the "silent" publishers of the 1855 and 1856 editions of Leaves of Grass, and of Whitman's relationship to his patron, Emerson. Phorniosticus claimed that he too had "sat on the lap of Paumanok, and heard the little Child say softly-amid the hoarse, heaving breaths of the Old Mother, as W. W. put it:-"

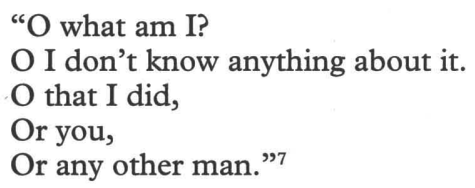

The parody echoes "A Child's Reminiscence" (later "Out of the Cradle Endlessly Rocking”), which had appeared on December 24, 1859, in another New York periodical closely aligned with the New York bohemians, Henry Clapp's Saturday Press. ${ }^{8}$ Searching for what he called "the outward manifestations of the divine ME," the writer confesses his frustration. Not Whitman's poetry, not the phrenologists at Weller \& Fowls - who had, he reports, actually examined his head - and not even the great philosopher of the R.A.F. Waldersonian Schools had satisfactorily answered the question of questions: what is the meaning of life? He had no choice but to develop his own philosophy, not, as had Carlyle, by devising a philosophy of clothes, but by formulating "The Aesthetics of Boots." Here too the example of Whitman and his critics offered an essential lesson: "I had noticed that mysterious Something about Boots myself. I remember thinking at first that it was like what the Saturday Press said about Mr. Whitman's poems, 'The meaning is subtle and well enveloped, eluding definition,'-I think that was it." "9

Not counting the five-line echo of "Out of the Cradle" quoted above, Vanity Fair published at least five parodies of Whitman, each of which I shall reproduce below. One of these, "The Song of the Barbe- 
cue. Not by Walt Whitman, nor Professor Longfellow," published on September 29, 1860, pays Whitman the compliment of conflating his work with that of the revered Longfellow-or more accurately from the perspective of Vanity Fair, it pays Longfellow the compliment of being associated with Whitman. These parodies-along with Vanity Fair's running series of comments, puns, comic asides, and references-paint a revealing picture of Whitman as a poet whose "barbaric yawp" already was being heard and understood, at least by the readers of a comic weekly that quickly "created a considerable stir" by offering "live, topical, substantial fare," as Charles I. Glicksberg put it. ${ }^{10}$ Not restrained by notions of propriety-sexual or otherwise - the wits who wrote for Vanity Fair expressed their affection for Whitman and respect for his genius even while poking fun at his idiosyncratic behavior and parodying his style.

In analyzing Vanity Fair's treatment of Whitman, I will also consider the periodical's precarious position as a comic magazine at a time of impending national dissolution and then of civil war. Initially the editors claimed to be non-partisan in their use of humor and satire, skewering folly wherever it was to be found: in politics, society, and the arts - north, south, east and west. But political neutrality, always a myth, became impossible in the face of the polarizing questions of race and war. For most of its existence, the magazine became an instrument for the political opinions of its proprietors, who, as conservative Democrats, were resistant to Lincoln and also actively hostile to the Negro. In mid-1863 Vanity Fair, its racism having alienated many potential readers among its natural allies in the liberal community and faced with sharply escalating production costs, would be forced to suspend publication. It too became a casualty of a war that it had hoped to ward off with gentle humor. The previous December, Whitman had moved to Washington, where his support for the policies of the Lincoln administration would intensify.

The Bohemian Origins of the "First Measurably Successful Comic Weekly"

Frank Luther Mott writes that Vanity Fair was "born in Pfaff"s cellar, bohemian gathering place of the wits of the fifties" in New York. Since Whitman was a regular at Pfaff's from 1859 through late 1862, he most likely was present when ideas for a humorous weekly were being bandied about. Just who conceived the idea remains unknown, but the responsibility for creating and sustaining the magazine must be assumed by three brothers named Stephens. William Allan became editor-inchief, Henry Louis served as the magazine's principal cartoonist, and Louis Henry its "Publisher for the Proprietors." In the Baltimore merchant Frank J. Thompson, a close friend of Henry Louis Stephens, the magazine had the financial angel, the proprietor, who made publication 
possible. Mott based his sketch of Vanity Fair in part on interviews with the sons of Henry Louis Stephens, W. P. and Frank Stephens. The weekly's managing editors were Frank Wood, 1859-1860; Charles Godfrey Leland, 1860-1861; Charles Farrar Browne (Artemus Ward), 1861-1862; and Charles Dawson Shanly, 1862-1863. ${ }^{11}$

Here is how the magazine presented itself in an ad reproduced the way it had appeared in Harper's Weekly on February 4th, 1860:

\author{
VANITY FAIR. \\ THE NEW COMIC ILLUSTRATED PAPER \\ IS TAKING THE WHOLE UNION BY STORM! \\ Every number abounds in \\ SIDE-SPLITTING FUN, \\ DELICATE HUMOR,
}

SMASHING SATIRE, and all the other characteristics that should belong to an

INTENSELY HUMOROUS JOURNAL.

\title{
VANITY FAIR
}

is a Thoroughly Live Paper, in the most vivacious acceptance of the term. The extraordinary popularity it has already acquired is only the inevitable result of its excellence and spirit.

Price Six Cents. For sale by all Newsmen.

Specimen copies sent on receipt of two Postage Stamps.

FRANK J. THOMPSON, Publisher and Proprietor,

No. 113 Nassau Street, New York. ${ }^{12}$

In their introductory remarks and in a piece on "Politics" from the first issue, the editors assured readers that they would not approach their task with the "cruelty" typical of such endeavors. Vanity Fair would not "correct with a stab, and heal with a poison," but would use "gentleness," since "more can be accomplished by good-humored raillery than envenomed wit." But was this a time for gentleness? Vanity Fair acknowledged the threat of national disunion, but refused to "be alarmed by these politicians . . . for whatever they may say . . . we shall still believe that the country is safe." The best way to keep it safe would be to deploy humor, for "The one great panacea for social and political evils is mirth." Inviting its readers to join with it in "laugh[ing] all the Disunionists out of countenance," Vanity Fair would "take the Union henceforth, and, till further notice, under its wide-spread and protecting wings." The worst sin that they or anyone could commit would be to become serious, since "the moment men become serious they become knavish." 13 While such a philosophy might be tenable in times of peace, and while its satire frequently hit the mark as applied to literary and social topics, it would come to ring hollow in view of the threatand then reality - of civil war. 
As I have mentioned, the magazine's proprietors were Union Democrats-decidedly not Copperheads, but hostile to Lincoln and Greeley and throughout its existence dismissive in an ugly way of the cause of the Negro. Perhaps, they felt, if Vanity Fair could satirize the extremists on both sides - uncompromising Secessionists in the South and Abolitionists in the North-the center would hold. The moral failure of the paper, as Don C. Seitz has observed, "was in its refusal to accept slavery as an issue and in its appeal to good humor and common sense in seeking to ward off the crisis. Vanity Fair wanted to save the country by getting rid of the fire-eating Southern politician and side-tracking the negro - an impossible solution, as the event proved."14

In "Rev.Theodore Parker's Nightmare," published on March 17, 1860, Vanity Fair described the mood in New York as one of hope and relief: "We have all given up J. Brown in these parts. He is not mentioned unless it is absolutely necessary. The national air is clearer for that great thunder-bolt propelled into it by a strange destiny. The people are everywhere restored to their temper, and their business, and can afford to laugh at the frights and follies they were betrayed into by one old Round head, born in a wrong age." If only Boston learned to silence such Abolitionists as Wendell Phillips and Parker, "whose nightmare is Brown," Vanity Fair implied, and if only moderate Southern politicians could gain control over their fire-eating colleagues, the problem would take care of itself. ${ }^{15}$ Politically it continued to joke at the expense of ungainly Lincoln, the ignorant Negro, the irrational Greeley, "J. B." (James Buchanan), Secessionists and Abolitionists - even while training its guns on the manners, materialism, and moralism that long have been the staple of humorists.

It would not be long, however, before Vanity Fair itself became a political battleground, especially after its most effective editor, Charles Godfrey Leland, took over. Serving from July 1860 through late spring or early summer 1861, Leland, a strong supporter of Lincoln, the Union, and of Emancipation, did his best to move the magazine in the direction of Republicanism. However, as he recalled, "The manager of Vanity Fair [William A. Stephens] was very much averse to absolutely committing the magazine to Republicanism, and I was determined on it. I had a delicate and very difficult path to pursue, and I succeeded, as the publication bears witness." 16 Nevertheless, as Charles I. Glicksburg put it, since Leland's vigorous support of Lincoln and the war effort "proved a bone of contention between owner and editor," the editor's "services came to an end." 17 According Seitz, Leland "resigned and, going to Boston, started the Continental Magazine [actually the Continental Monthly (1862-64)] with the aid of an 'angel' and was radical to his heart's content-often too much so for the Lincoln Administration, which he tried to drive rather than serve." 18 His Vanity Fair associate, Charles Farrar Browne, took over. Leland recalled that "Browne agreed pretty fairly 
with me," but there is no denying that the paper lost its aggressiveness in championing the War as a moral crusade. ${ }^{19}$ In fact, on the question of the Negro, Ward's sensibility seems to have been compatible with the racism of Thompson and the Stephenses, since he "continued the magazine's policy of printing racist and anti-abolitionist jokes even after the Civil War was under way."20 In 1866, in an article on Artemus Ward, the North American Review claimed that although Vanity Fair had made a most promising start, its politics - and its being a copy of Punch-worked against it: "It was what is called conservative, and used the stale jests about negroes and philanthropy; while the class on which it needed to rely was in the main not conservative, but liberal, and opposed to its politics. Besides this, it was a copy of Punch . . . . The pictures were not quite so good ... and in fact it is too true that it was an American Punch." 11

While a significant portion of the magazine's potential audience may well have been liberal - at least as seen from the vantage point of Boston's North American Review-many in its core group of writers were conservative in the sense of being hostile to the policies championed by the Republicans. David S. Reynolds has pointed out that "like Whitman, the bohemians thought of themselves as opposed to slavery, but they had no sympathy for the abolitionists and Republicans who were fighting it." Reynolds quotes Henry Clapp's remark, made following Lincoln's election, that "we are opposed to slavery of every kind, but we are even more opposed to what is stupidly called anti-slavery, for the simple reason that it has no distinct aim or purpose, and consists of nothing but a series of noisy and unmeaning howls." Clapp went so far as to charge Lincoln with simply using the Negro "as a stepping-stone to power." Yet, Reynolds argues, it was the bohemians, not Lincoln, who "had no distinct aim or purpose. Unable to cope with the national crisis, they were playing a desperate game of evasion." 22

One must say, however, that if Whitman and his fellow bohemians were slow in coming around to Lincoln and the war, they were otherwise quick-witted. At Pfaff's it was "give and take . . . by the brightest minds in New York. The retold story and the repeated bon mot were rigorously barred, but the new good thing was sure of applause," Ferris Greenslet has written in his biography of Thomas Bailey Aldrich. ${ }^{23}$ The young Aldrich contributed both to Clapp's Saturday Press and Vanity Fair. Regulars and occasional visitors at Pfaff's also included Whitman's close friend and supporter Clapp, George Arnold, Fitz-James O'Brien (who tragically died of battle wounds on April 6, 1862), ${ }^{24}$ Charles D. Gardette, N. G. Shepard, Henry Neil, Browne (Artemis Ward), Wood, Adah Clare, Shanly, Fitz-Hugh Ludlow, William Winter, Richard Henry Stoddard, and Edmund Clarence Stedman, who called Vanity Fair the nation's "the first measurably successful comic and literary weekly." 25 Artists who visited included Launt Thompson, George Boughton, Wil- 
son Fisk, Edward F. Mullen, Frank Bellew, and Sol Etynge, Jr. ${ }^{26}$

"There was not much of a literary market at that time," Stedman recalled. "Newspaper salaries were very low. There were few magazines, and scarcely any but Harper's and the Atlantic paid much of anything. New York itself was not literary and looked with distrust, if not contempt, upon working" writers. Still, whatever their troubles or hardships, those who gathered at Pfaff's "were all very merry," as Aldrich wrote in "At the Café," published in Vanity Fair's first issue, December $31,1859 .{ }^{27}$ They created a supportive literary community, even as they seized the opportunity to satirize one another and especially the respectable press. "These people were mostly from the country," Stedman explained to a reporter for the New York Herald in 1890, following the death of Henry Clapp: "They had scarcely any acquaintances in the city outside of their profession. You can easily see that they were thrown back upon themselves and made the most of that artistic, happy-golucky bonhomie and comradeship." ${ }^{28}$ Seitz points out that Artemus Ward came to Pfaff's "as one to the manner born. The evenings were gay with converse and many libations of Pfaff's brew. . . . The members were men of genius, kinsmen in the world of light, who came here to meet their brothers." 29 The Pfaffians sought to infuse that light, humorous, but pointedly satiric style into Vanity Fair. What better way to get back at the prominent, self-important, and pretentious periodicals and newspapers that didn't pay them or hire them or notice them than with satire? And what better way to promote each other's work, Henry Clapp saw, than with a barrage of press notices-even negative ones-that could make a public personage of a writer like Whitman? "Clapp's prescience lay in his comprehension of how publicity and celebrity could, within a changing literary market, obviate the need for critical and moral approval," Christine Stansell has observed. ${ }^{30}$

While the bohemians initially remained aloof from Abolition and other social reforms, one cause that seemed to draw many together was sexual liberation. Clapp himself had been arrested for leading a freelove rally, and Adah Clare, who gave birth out of wedlock, and Menken, who had appeared on stage in a translucent body suit, flouted conventional morality. It was at Pfaff's at this time that Whitman apparently met a lover, Fred Vaughan, ${ }^{31}$ and socialized with members of the "Fred Gray Association," an informal group of young male friends. ${ }^{32}$ Whitman has left us an unfinished poem, "The Two Vaults," describing the irreverent, largely masculine atmosphere at Pfaff's:

- The vault at Pfaff's where drinkers and laughers meet to eat and drink and carouse While on the walk immediately overhead pass the myriad feet of Broadway

As the dead in their graves are underfoot hidden

And the living pass over them, recking not of them,

Laugh on laughers!

Drink on drinkers! 
Bandy the jest!

Toss the theme from one to another!

Beam up-Brighten up, bright eyes of beautiful young men!

Eat what you, having ordered, are pleased to see placed before you-after the work of the day, now, with appetite eat,

Drink wine-drink beer-raise your voice,

Behold! your friend, as he arrives-Welcome him, where, from the upper step, he looks down upon you with cheerful look. ${ }^{33}$

Even more revealing, in poems from the "Calamus" section of the 1860 Leaves of Grass, Whitman called attention to a new style of urban life, one in which men gathered in bar rooms such as Pfaff's. In "A Glimpse," the speaker meets "a youth who loves me and whom I love." In "City of Orgies" Whitman praises Manhattan as the place where "the frequent and swift flash of eyes" offer "me love, / Offering response to my own - these repay me, / Lovers, continual lovers, only repay me."34

Similarly, in "At the Café," which evidently he did not reprint, Aldrich spoke of Pfaff's as a place where masculine friendship could compensate for other disappointments, including being jilted by a "false" woman:

We were all very merry at Pfaff's. Did you think

While I laughed with the rest, just a trifle too gay,

That ma mignonne was false, that I buried my friend,

That my castles in Spain had been plundered that day-

Did you think?

Did you think, as you watched me and weighed every word,

And then smiling complacently, understood all,

That my heart, as I passed the Rhine wine to the boys,

Was as black as the midnight, and bitter as gall-

Did you think?

Did you think that those small, wary, twinkling gray eyes,

That look over and under and into things so,

Could read me - a primer? that you could let drop

A sly plummet right down the depths of my wo-

Did you think?

You will kill me with laughter, some day, you dear owl!

I was happy that night, though the girl was a cheat:

Could I grieve for a flirt, when the man that I loved

Was so sweetly at rest from his head to his feet-

Did you think? ${ }^{35}$

Does the poem hint at a homosexual attachment? Who is the man "so sweetly" at rest? Are men more to be trusted than flirting, cheating women? The poem is purposely ambiguous, but it presents Pfaff's as a place where sexual boundaries are fluid, where men and women are freely drawn to each other-without the evident sanction of marriage. 
That Vanity Fair published in its first number a poem associating itself with Pfaff's, with its reputation as a bohemian gathering spot for men and women who believed in free love, signaled its willingness to espouse a new, characteristically New York openness to sexual subjects.

There was a definite hypocrisy for at least some of its writersthose who published suggestive material in Vanity Fair but refused to be associated with it. For instance, John Godfrey Saxe published several risqué poems - for which he accepted a dollar each-but only on the condition, as he wrote to Leland, that his name not be associated with the magazine. ${ }^{36}$ One of these, "Conjurgium non Conjugium," appeared on August 4, 1860:

Dick leads, it is known, with his beautiful wife-

In spite of their vows- such a turbulent life;

The social condition of Dick and his mate

Should surely be called the conjurgial state. ${ }^{37}$

Part of the attraction of the magazine, for readers and contributors alike, was its willingness to publish material that could not appear in mainstream literary outlets and thereby to speak of social realities that could not otherwise be acknowledged.

Vanity Fair would be a magazine for grown ups. The author of a short article published on April 14, 1860, titled "The Force of Example," remarks:

It is pleasant for us to know that Vanity Fair is doing any humble thing in the cause of early piety. As an immediate result of the Juvenile Library, see this from the advertising columns:

"The Independent will hereafter be made as attractive to children as to full-grown Men and Women."

But what is this but an attempt to make capital out of our enterprise? All fullgrown men and women know that they have always been treated like Children by the Independent. ${ }^{38}$

Reflecting the openness and tolerance of the Pfaffians, Vanity Fair trained a satiric eye on the sanctimoniousness of the religious press and on the hypocrisy of the self-appointed guardians of public morality. Henry Ward Beecher was a favorite target.

In "The Town" from its first issue, Vanity Fair asserted that "If it be true that ... God made the country and man the town, then the town needs some one to take care of it." Who better to take care of a town like New York and its denizens than a smart humor magazine, as the writer observed: "The town, too, is the centre of Vanity Fair, the point where all its good and all its wickedness is sublimated, where everybody, according to the best authority, is travelling in the broad road 
that leads first to the Battery and afterward to no matter where." The author introduced the public to a new cast of characters-New Yorkers to the core-that included a former showgirl, "Carrie-Jane, or Jennie, as they modernise it," and that wealthy young man about town, "J. Coupon-Dore, Esq . . . neither of whom you, sir, or madam, would be surprised at meeting anyplace outside the Tombs." 39 Whitman, it would show, was very much a product of this new, urban environment.

Not much is known about Whitman's relationship with Vanity Fair's first editor, Frank Wood-or about Wood himself. But there is every reason to believe that the second editor, Charles Godfrey Leland, had a strong interest in Whitman's work, as, we know, Whitman did in his. Leland had translated Heine's Pictures of Travel (1855), a book Whitman read in 1856 and kept with him over the years. He would refer to it on several occasions in conversation with Horace Traubel, calling it "a joy and a delight." ${ }^{\prime 40}$ Further, in 1849 Whitman had clipped four articles by Leland on literature and art from Sartain's Union Magazine. ${ }^{41}$ Perhaps even more important, Leland's younger brother Henry was also an important early friend and supporter of the poet, sending Whitman two articles on his poetry that he had published in Philadelphia papers. On June 12,1860 , Whitman wrote to Clapp with the express request that these pieces be published in the Saturday Press. ${ }^{42}$ Stricken by severe heat prostration during his war service, Henry Leland died in 1868. Some twelve years later, Whitman told Charles Leland that during a period of great despondency, "in the darkest years of his life, when he almost despaired"-evidently after the failure of the 1856 edition-he had received from Henry Leland "a cheering letter, full of admiration, which had a great effect on him, and inspired him to renewed effort." 43 In response, as Charles Leland told the story, Whitman "sent my brother a copy of the first edition of his Leaves of Grass, with his autograph, which I still possess. I knew nothing of this till Whitman told me of it. The poet declared to me very explicitly that he had been much influenced by my brother's letter, which was like a single star in a dark night of despair, and I have no doubt that the world owes more to it than will ever be made known." ${ }^{44}$ It is likely that the two discussed ways of continuing to include Whitman in the weekly.

Did Leland and the other editors publish Whitman in Vanity Fair? The author of the anonymous entry on Whitman in the National Cyclopedia of American Biography (1893) asserts that Whitman "wrote for Vanity Fair and other comic or satirical papers in New York, and was a recognized member of a group of young 'Bohemians,' as they were called, made up of musical, dramatic and literary critics attached to the daily and weekly press. At this time he led the life of a free-lance." 45 The article is unsigned, but since the volume includes John Burroughs's name on the list of contributors, he may well be the author-in which case the source could well be the poet himself. Glicksburg concluded that 
"Whitman was probably a contributor, though none of his material has as yet been identified." 46 It seems unlikely that Whitman would have been comfortable regularly turning out the sort of comic pieces that were the periodical's mainstay-puns, parody, and burlesque. On the other hand, since Vanity Fair satirized figures such as the corrupt mayor of New York, Fernando Wood, included articles about cultural life in New York and Brooklyn, published short book reviews, sketches of the city, and a variety of other material, including notices of periodicals, it is by no means inconceivable, perhaps even likely, that Whitman published in the magazine. After all, the bohemians from Pfaff's were the magazine's mainstay and he was a central figure in that group. The question of what exactly Whitman may have contributed deserves a separate essay.

\section{Vanity Fair and the 1860 Edition of Leaves of Grass}

As is well known, on February 10, 1860, the Boston publisher Thayer and Eldridge wrote to Whitman proposing to bring out a new edition of his work. Whitman of course accepted, and during March, April, and May of that year he was absent from the table Pfaff reserved for writers so that he could supervise the publication of the new edition, which appeared that May. ${ }^{47}$ Nevertheless, it appears that he remained in touch with Clapp, Fred Vaughan, and possibly other New York friends from Boston. As Clapp wrote him on March 27, "I need not say, we are all anxious to see you back at Pfaff's, and are eagerly looking for your proposed letter to the crowd." 48 During the first six months of the year, Vanity Fair published some five references to Whitman, two of which, a parody on "counter jumpers" and a reference to that year's crop of calamus, would seem to bear importantly on the new volume.

In the March 10, 1860 issue, the first reference to Whitman is part of an article on "Ages of American Authors" that pokes fun at an emerging style of treating authors-especially New Englanders-as hallowed figures. Vanity Fair playfully criticizes these puff pieces as violations of journalistic ethics. But if such pieces are to appear at all, why then an important periodical like Vanity Fair must assume the august responsibility of correcting the record and insuring that all the truly important writers - mostly New Yorkers such as Whitman and Fanny Fern - are included. Singled out for criticism is "The Boston Transcript, that great authority in literary matters," which has been "favoring the world with the ages of several American literary notabilities. Some people, and the ladies especially, may regard this sort of thing in the light of impertinence, but we cannot help it if they do; it is the legitimate duty of journalists to furnish their readers with the little tit bits which their appetites crave. ... The Transcript having made a few blunders and several omissions, we have fortified ourselves with divers facts on this highly inter- 
esting subject, which we proceed to lay before our expectant readers." Consequently, we learn that "The author of Leaves of Grass is 81 (his youthful appearance may be attributed to vegetable diet)." The ages of other writers are variously given. For instance, Fern is 19; both Stoddard and Aldrich "will be 21 on the $4^{\text {th }}$ of July next." Henry Clapp, Jr., is 101, and "Mr. Henry C. Carey is of the same age as Adam Smith." Readers learn that "Fitz James O'Brien is 51 (but looks older)." Parke Godwin and Parke Benjamin "are both in their $71^{\text {st }}$ year. . . Charles F. Briggs baffles all inquiry, but is at least 80 ; Henry T. Tuckerman pretends to be not more than 62 , but, as he remembers Washington, and often speaks of Doctor Franklin and Joel Barlow, he must be past 82.” Vanity Fair mentioned one of its regular targets, James Gordon Bennett of the Herald, whose age is given as 91, even though he is "supposed to be a trifle older." The paragraph concludes with a statement vouching for the factual truth of the information, but "if we have mis-stated the exact age of any literary lady or gentleman we shall be most happy to correct the mistake on the receipt of refuting vouchers." 49

After mentioning the age of the author of "Leaves of Grass," Vanity Fair comments that "the age of the author of 'Leaves from Nature' is uncertain, supposed to be still in his teens." The reference is to Maximilan Schele de Vere, whose Stray Leaves from the Book of Nature, a work of popular science, was published by G. P. Putnam in 1855 . Whitman had studied de Vere's Comparative Philology (1853), which included a chapter on American English, enabling Whitman to take pride, according to Joseph Jay Rubin, in "be-

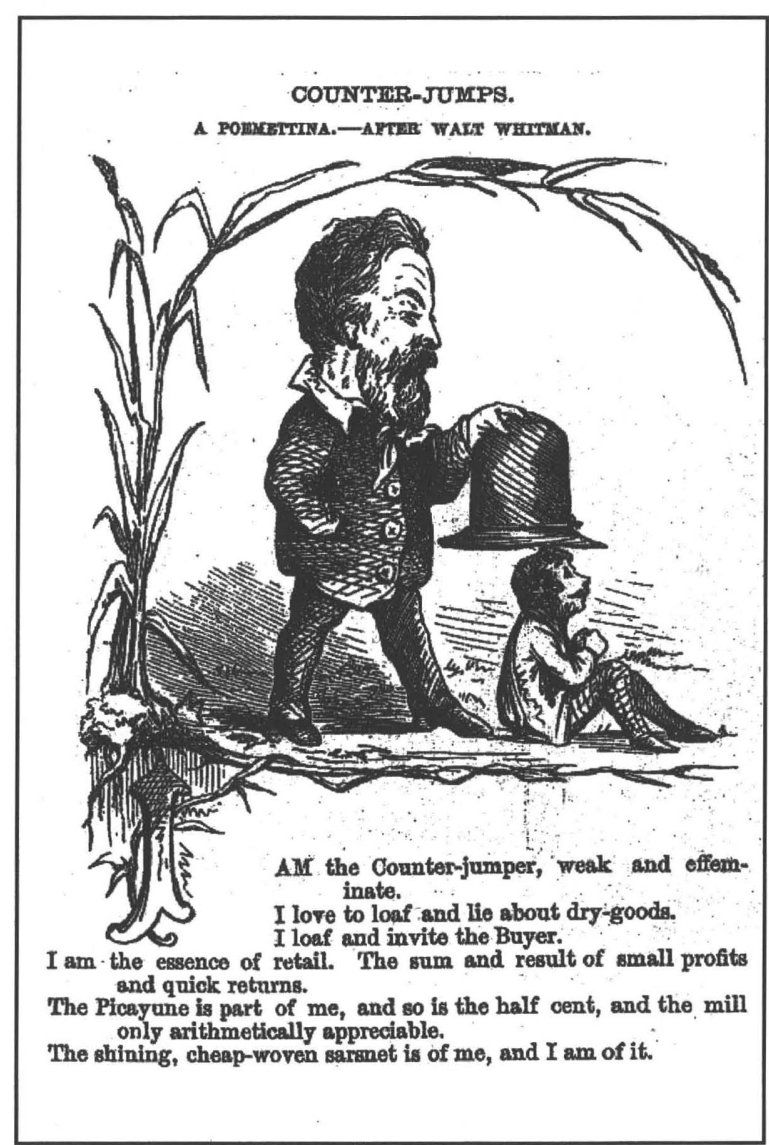

Figure 1 
longing to the small, but majestic band of 'language-searchers."' 50

A week later, on March 17, Vanity Fair published a revealing twentyfive line parody, "Counter-Jumps. A Poemettina.-After Walt Whitman," in which "Whitman" identifies himself as "counter-jumper," a term apparently coined by the magazine to refer to the well-dressed male clerks who worked in the fashionable stores catering to women. The term counter-jumper became one way of speaking about the emergence of an urban homosexual culture, as the historian Bert Hansen has suggested. ${ }^{51}$ In having "Whitman" characterize himself as a counterjumper, Vanity Fair associates the poet with this culture. The timing of the parody is intriguing; two months later, with the publication of the "Calamus" section of Leaves of Grass, the poet himself would publicly celebrate the world of intense male attachments.

Vanity Fair's parody includes a large drawing of Whitman as bearded poet standing above and behind a seated younger man (see Figure 1). The poet is holding an enormous hat in his left hand as if ready to envelop the seated figure - the hat itself is about the same size as the seated man, who seems entirely in Whitman's possession. Would Whitman's fellow denizens at Pfaff's have recognized this as a portrayal of his relationship with a particular individual, say Frederick B. Vaughan? According to Charley Shively, Vaughan "lived with Walt Whitman while the poet finished his 'Calamus' poems which their love helped to shape. ... In 1860 Whitman sent Vaughan galleys from Boston when the 1860 edition went to press." ${ }^{\prime 2}$ Is the plant that rises from the ground and crowns both him and the seated figure meant to be the calamus itself? Two months later, as we will see, Vanity Fair would refer to prospects for the calamus crop in 1860, a likely reference to Whitman. If the drawing is meant to carry sexual overtones, then the poem itself reinforces those suggestions:

\section{COUNTER-JUMPS.}

A Poemettina.-After Walt Whitman.

I am the Counter-jumper, weak and effeminate.

I love to loaf and lie about dry-goods.

I loaf and invite the Buyer.

I am the essence of retail. The sum and result of small profits and quick returns.

The Picayune is part of me, and so is the half cent, and the mill only arithmetically appreciable.

The shining, cheap-woven sarsnet is of me, and I am of it.

And the white bobinet,

And the moire antique, thickly webbed and strown with impossible flowers,

And the warm winter gloves lined with fur,

And the delicate summer gloves of silk threads,

And the intermediate ones built of the hide of the Swedish rat,

All these things are of me, and many more also.

For I am the shop, and the counter, and the till, 
But particularly the last.

And I explore and rummage the till, and am at home in it.

And I am the shelves on which lie the damaged goods;

The damaged goods themselves I am,

And I ask what's the damage?

I am the crate, and the hamper, and the yard-wand, and the box of silks fresh from France,

And when I came into the world I paid duty,

And I never did my duty,

And never intend to do it,

For I am the creature of weak depravities;

I am the Counter-jumper;

I sound my feeble yelp over the woofs of the World..$^{53}$

The poet who in the first three editions of "Song of Myself" identifies himself as "Walt Whitman, an American, one of the roughs, a kosmos," here confesses that he's just another "weak and effeminate" counterjumper. ${ }^{54}$ This clerk-writer refuses to do his "duty," because he is "the creature of weak depravities."

Yet, there is nothing malicious about this or other parodies of Whitman. The "homosexual" had not yet been created as a social type, and same-sex love had not yet been stigmatized as a moral failing, something that would not take place until the last third of the century, beginning, according to Hansen, around 1870, when there began to develop "a new public discourse, primarily medical, about the homosexual as a type of person." ${ }^{55}$ What is most significant in this context is that Whitman's associates in the Pfaff's/Vanity Fair community could publish the parody without harming the poet's reputation. During 1860 Vanity Fair published at least fifteen articles on "counter-jumpers." The parody develops another theme as well: the way that literature had become part of the new culture of advertising, publicity, and commerce. Poetry too is a commodity. In fact, by 1860 , as Justin Kaplan has written, Whitman's "dealings with editors reflected a new self-regard and assertiveness" on the economic value of his work. ${ }^{56}$

The Vanity Fair issue for April 14 contained two references to Whitman. The first occurs in the course of a satire on Senator Louis T. Wigfall of Texas (1816-1874), an aggressive champion of the Secession. Harper's Weekly recently had described him as a masterful "orator-probably the most charming in the Senate . . . . He speaks grammatically, elegantly, and without effort . . . He is witty and smart." 57 Vanity Fair satirizes Wigfall, the champion of slavery, by calling him "one of the embodiments of the Republican idea, one of the mighty bulwarks of the constitution, one of the living illustrations of the beauty and majesty and ease of self-government. In time of trouble, we shall have to turn to Wigfall. . . . His utterances are those of an accomplished and popular oracle. Go to, Walt Whitman, thy slabs of wisdom are all in a crumble compared with the granitic chunks that fall from Wigfall!" 58 
The essay suggests another dimension of Whitman's persona in 1860as the unyielding champion of American democracy-and it reflects Vanity Fair's policy of satirizing Southern firebrands along with Abolitionists.

That same issue in April contained another short reference to Whitman:

A True "Barbaric Yawp."

The milkman's morning cry. ${ }^{59}$

This casual allusion to Whitman suggests just how well-known his work was - at least among readers of Vanity Fair. The editors assumed that their readers would understand the reference to the poet who in "Song of Myself" bragged that "I too am not a bit tamed ... I too am untranslatable, / I sound my barbaric yawp over the rooftops of the world." 60

On May 19, the Saturday Press published an extensive review of the new edition of Leaves of Grass. ${ }^{61}$ As if in preparation for the appearance of the new volume, some nine days earlier, on May 10, 1860, Vanity Fair published an extraordinary piece, "Our Agricultural Column: Crop Prospects for 1860," meant, I take it, to welcome Whitman back to New York from Boston. A parody of the familiar newspaper and magazine article on the prospects for various agricultural crops, the piece comments on the prospects that year for pork, peanuts, old rye, bowie knives, and the calamus root, where an outstanding crop was expected. Evidently the bohemians at Pfaff's knew that in the new edition Whitman would introduce the calamus as the primary symbol of male friendship. Here is Vanity Fair's entry on "Calamus":

\section{Calamus}

There will be a heavy crop of this health-giving root. We observed its graceful blossoms in many a meadow. Some of the farmers complain of the effects of heavy rains, and others anticipate a falling-off on account of the severe drought; but the general feeling is one of pride and hope. In consequence of the failure of the tobacco crop an unusually active market for Calamus is expected this season. The rates will rule higher. We believe roots will be held at more than one cent each. But we shall be well prepared to bear this slight advance, the effects of the Crisis of ' 57 having entirely passed away. ${ }^{62}$

Whitman himself would return from Boston in a few days, as the Pfaff's crowd well knew. It is impossible to read this reference as anything other than a statement of "pride and hope" on the part of the Vanity Fair-bohemian community on the prospects for Whitman's new edition. His friends at Pfaff's well understood that he, like the market for calamus, had been depressed following the failure of the 1856 edition. They shared his new-found optimism and confidence in his literary prospects in 1860; this notice is a way of wishing him the best at a 
pivotal moment in his career. If I am correct in reading the paragraph on calamus as a reference to the contents of the new volume, it would suggest that Whitman shared his plans for the book, including "Calamus" and "Enfans d'Adam," with his bohemian associates.

\section{Leland and the Short-Lived Strike of the Bohemians}

In his Memoirs, Charles Leland recalls that as a result of "some difficulty or other" with the management of Vanity Fair, Frank Wood left his editorship after approximately six months, and that he was "followed by all the clan." That is, the Pfaffians, expressing support for Wood, refused to contribute. Consequently, Leland was called in to edit the magazine in "the emergency, and what with writing myself, and the aid of R.H. Stoddard, T. B. Aldrich, and a few more, we made a very creditable appearance indeed. Little by little the Bohemians all came back, and all went well." "63 As Charles I. Glicksberg's analysis of Leland's correspondence reveals, the new editor sought to broaden the magazine by soliciting such Boston writers as Lowell and Holmes. His own contributions seem to have won a certain popularity. Lowell, unaware that Leland was the author of a series of travel sketches written under the name Broadway Spuytenfeufel, praised the "Rabelaisian humor \& tothe-back-bone Americanism" of the series. ${ }^{64}$ On October 10, Vanity Fair created a sensation with Stedman's "The Prince's Ball," a satire on the hysteria surrounding the visit of the Prince of Wales to New York. ${ }^{65}$ Further, Artemus Ward began contributing at this time. "Artemus Ward Visits Brigham Young," published on November 10, 1860, also was a hit. ${ }^{66}$ Needless to say, the imaginative Ward never traveled to Utah to meet the Mormon leader and his wives! Even as he steered the weekly toward the Republicans and sought to attract New Englanders, Leland continued to refer to a larger-than-life poet who was just too much fun to be ignored.

On July 7, 1860, Vanity Fair published a full-scale parody of Whitman as a poet who had drawn heavily from familiar patriotic rhetoric. Titled "The Torch Bearer," the parody appeared in the Saturday Press that same day, suggesting the close connection between the two periodicals:

The Torch-Bearer

A Paean for the Fourth of July.

(After Walt. Whitman.)

1. I celebrate the Fourth of July!

And what I celebrate you shall celebrate,

And all together we'll go in strong for a celebration.

2. Over sea, hither from the gates of the morning,

Jubilant, haughty, the glad day of America returns! 
Comrade Americans, foreign elements,

German persons, Irish and otherwise,

Hurra for our side!

3. When, terrible in the midnight, begins the wild roar of canon;

When the ear-cracking cracker awakes me with its continual cracks;

When punch and confusion are in the house and the "morning call" is brought to me in a tumbler;

When the stars and stripes hang round in a very miscellaneous manner;

When Broadway is entirely given up to patriotic youth - then Young America bristles;

When the police are in a state of mind and the Aldermen in a state of body;

When in point of fact there is the devil to pay generally; -

Then is the Fourth of July, and I, rising, behold it.

I descend to the pavement, I swerve with the crowd, I roar exultant, I am an American citizen, I feel that every man I meet owes me twenty-five cents.

Selah!

4. I don't know if other folks see so much as I do,--but I incline to think they don't.

Especially I think they don't see paying me a quarter.

At any rate they don't pay it.

N'importe! I see it all the same,-a kaleidscope of flowing and glancing coins!

I salute you. Eagles - birds of success! Female figures-mothers of luxury!

Stand by me on this occasion, Eagles and Females!

Stand by me that I may celebrate - that I may witness and greet the ascending shapes!

5. The shapes arise.

Shapes of urchins, ragged and dirty-faced, popping off pistols at the unwary pedestrians;

Shapes of citizens upon the house-tops, patriotic, hurling the explosive torpedo;

Shapes of Aldermen and Members of Common Council, drunk with enthusiasm and Old Jamaica;

Shapes of omnibus drivers, idiotic and bawling, the crackers muttering under their horses feet;

Shapes of the prayers that are disappointed of their prayers-

Prayers of the "Fulton-street Daily Prayer-Meeting," adjourned to the $5^{\text {th }}$, for a reason-

Shapes of the mild ecclesiastics, sleek, black-coated, white about the neck, enraged at the cheerful noises;

Shapes of inebriated editors, the Pecksniffs of the Times and of the World;

Shapes of jolly printers, festive, uproarious, who won't on any terms go home till morning;

Shapes of the papers that are not published next day;

Shapes of steamboats that dot the harbor and the river, carrying the excursionists to rural delights;

Shapes of the rural delights - the frisky locust, the bug, omnipresent, the lively worm, the flirtation in the bush;

Shapes of the bulky Germans, slow of appreciation, drinking their Lager Bier;

Pipe shapes; shapes of the smoke-cloud, Irish persons enveloped;

Shapes of the Irish persons brawling, the whiskey mastering their brains;

Shapes of the "stars" and "shadows," alert for the wranglers and those who fight;

Shapes of the sharpers, courtesans, whiskered persons, collecting revenue;

Shapes of counter-jumpers, redolent shades, mint-julips attending; 
Shapes of women, fair and otherwise, hungry for ice-cream and for lemonade;

Shapes of the ice-cream and the lemonade-disappearing shapes, the contact of sweet lips assisting;

Shapes of adventurous persons in balloons, my own shape soaring in the balloon of my fancy; -

And then, beautiful to see, the stars and stripes proudly fluttering over all.

6. The shapes arise!

The shape of a civic procession, a Mayor in the midst, Polyphemus, having "a single eye":

The shape of a Governor, military persons attending, a noise of horns and of drums;

The shape of the speaker, the air excessively sawed, coat-tails streaming in the wind;

The shape of Mr. Yeada's “Orator, Patriot, Sage, Cicero of America, Laudator of Washington, Apostle of Charity, High Priest of the Union, and Friend of Mankind;"

The shape of a philosopher, contemplative, seeing all, thinking what it is all about.

7. That philosopher am I.

I chant the American Eagle, the biggest bird out,-out too with his mother's knowledge.

I chant America, the great Ostrich of nations, destined to swallow up all the rest.

I chant the Fourth of July, birth-day of the Republic, glorious anniversary.

And what I celebrate you shall celebrate-as I had the honor of saying in the first place. ${ }^{67}$

I have not been able to identify the reference to Mr. Yeada in the sixth section, except that it may well refer to Whitman himself as the great patriotic orator of America. The parody captures Whitman's use of catalogues - and reveals that one source of Whitman's style is the all too familiar spread-eagle, extreme patriotic rhetoric of Fourth of July. And it defines Whitman as an urban poet-it is in the great metropolis that he finds the characteristic types and subjects of his verse, even if he ignores their penchant for alcohol. As Whitman sought to describe the American nation through his uplifting catalogues, so too does the author of this poem, but here the great American procession is revealed as a nation of sharpers, prostitutes, drunkards, politicians on the takeeven a poet desperate for a quarter. Is there an American who is not drunk on Independence Day?

The next month, on August 4, 1860, Vanity Fair returned to Whitman, this time in the course of a satirical two-part article on "Private Libraries of New York." The satire was provoked by the appearance that year of James Wynne's Private Libraries of New York, published by E. French. This book, which describes some fifty-one libraries, had its origin as a series for the New York Post. ${ }^{68}$ The hard-working, impoverished authors of Vanity Fair satirize the pretensions of wellhealed bibliophiles, who spend vast sums for foreign books - which, of course, they never read. In mocking the reverential tone of James Wynne, a temporarily unemployed medical doctor, Vanity Fair describes the 
rare qualities of books by New York authors, including Whitman: "To begin with the collection of Mr. Furnace. Among its curiosities are The Sinless Child, original edition, published by Keese; The Rape of the Lock, written by Pope Alexander, whose name reversed appears on the title page; the prose works of Walter Whitman, the great American Kosmos, (no connection of Humboldt's); the complete works of Paul de Kock edited by Tome, and the new edition of Casanova, a decoction lately recommended by the World." 69 Alexander von Humboldt's Kosmos had appeared in English in five volumes, and in 1860 Whitman had included the short poem "Kosmos."70 The reference to Charles Paul de Kock is most suggestive, because the French author was known for his pornographic fiction. ${ }^{71}$ On the other hand, The Sinless Child was one of those saccharine long poems dealing with a pure and pious heroine named Eva-reflecting the contrast between the worldly de Kock and the purity of Elizabeth Oakes Smith's heroine. ${ }^{72}$ One purpose of "Private Libraries of New York" is to suggest that the wealthy book collectors were not, after all, readers, as the magazine wrote in its next installment: between ourselves, dear readers of Vanity Fair, the bibliopole seldom gets beyond the cover of his books. To do more than this is to become a reader, which your true bibliopole never is."73

The next reference to Whitman appeared only a week later, on August 11, as part of a multi-part series titled "Telegraphic Tour," poking fun at the emerging style of travel writing. Its conductors are "Broadway Spuytentufel and his cousin Peytona Randolph of Accomac"Charles Godfrey Leland himself. It promises to take readers "Up the Middle, down the Sides, and Criss-Cross the whole Manifest Destination of the Universal American Continent." In Chapter VII the tour traverses the Catskill Mountains. In the course of a description of a particularly outrageous old widow, the author remarks that she "has been for seven years like my prose, and Walt Whitman's poetry, Beecher's theology and Andy Davis' Harmonicon, outside of all criticism - 'might as well criticise porcupine'-so people let her slide in peace and exclaim in cheerful awe 'did you ever!!'”74 These humorous references establish important connections between Whitman and both Beecher and Davis. Andrew Davis was a spiritualist, who, David S. Reynolds has written, helped bring to "the fore new kinds of mysticism and spiritual eroticism that Whitman would experiment with in Leaves of Grass." Further, Davis's popularization of "mesmeric healing, trance writing, and mental space-time travel through what Davis called 'traveling clairvoyance' . . . were manifested in Whitman's poetry."75 And we know that in forming his own style, Whitman "paid considerable attention to the oratory of influential ministers like Henry Ward Beecher."76

On September 15, 1860, Vanity Fair warned, as we have already seen, of the threat to overly sensitive young women of reading the wrong authors. If reading Milton could place someone in the asylum, then 
either Adah Menken or Whitman would push them right over the edgeperhaps forever. ${ }^{77}$

Two weeks later, on September 29, 1860, another parody of Whitman appeared; "Song of the Barbecue" satirized in one and the same poem both Whitman and Longfellow. The author may well have been aware of Whitman's apparent reference to Longfellow in "Poem of the Heart of the Son of Manhattan Island," in which Whitman writes, "And who has projected beautiful words through the longest time? By God! I will outvie him! I will say such words, they shall stretch through longer time!"78 The immediate references in "The Song of the Barbecue" are to Chapter XI, "Hiawatha's Wedding Feast," from Hiawatha and Whitman's "A Broadway Pageant," which had been published in the New York Times on June 27, 1860, under the title "The Errand Bearers."79 In "Hiawatha's Wedding Feast," Longfellow listed the "Haunch of deer and hump of bison," along with other foods served on the occasion. Similarly "The Song of the Barbecue" speaks of the "haunches" of the "bloody ox" served at a feast-this one a political gathering for Stephen A. Douglas. Whitman's poem commemorated the visit of Japanese ambassadors to America - and the huge parade in their honor up Broadway on June 16, 1860. There he sings of the triumph of "Libertad" through the joining of American liberty with "venerable Asia, the all-mother." Whitman makes no reference in this poem to the gathering storm of rebellion and civil war but rather projects an ideal image of world harmony and freedom.

Douglas gave his major speech at Jones Wood just outside the city on September 12. The poem satirizes the chaos and confusion surrounding Douglas's speech and attendant barbecue, which, according to the New York Times, attracted "an unprecedented multitude," drawn "largely . . . by the savor of roast beef, mutton and pork, grateful in the nostrils of a populace, whose favor is usually solicited through other avenues to the understanding." 80

The Song of the Barbecue.

Not by Walt Whitman, nor Professor Longfellow.

I sing not of the cue of Phelan,

I sing not of the actor's cue,

I sing not of the Roman Q,

I sing not of the cu-rious,

I sing of the Barbe-cue.

Held in the Wood of Jones,

Gathered there the rag-tail, Bob-tail also of the demies, Waiting for the ox to bake, Waiting for the cracker. 
Sensual am I, full of feeling

Hungry I get, at Meridian,

When the sun is high above,

Stomach shrieketh for victuals,

Thus I felt in Wood of Jones.

Soon the ox came, Libertad!

I sing of the fatted ox,

I sing of the ancient ox,

I sing of the smelling ox,

I sing of the bloody ox.

Ax inserted in his haunches,

Libertad! how it squelched.

Crowds crowd close around the tables,

Bread-trays wander to the crowd,

Small boys carry aforesaid Bread-trays.

Jerk it off from sirloin, rump,

Ribs or shoulder, haunch or quarter,

Throw it to the starving crowd,

Bloody, half-cooked, though it may be

Each Bite is a Bite for Douglas!

Libertad! Redad! Whitead! Bluead!

I sing of Douglas, little giant-

Travelling Duggy from the prairies

Ever shouting, ever bawling

"Tell me, pray thee, where's my mother!"

Now he speaketh-mouths are stilled, Jaws suspended in operation;

More meat cut up, more meat wasted, That Poverty would gladly smell of, Than I can tell thee in my poem.

I sing to thee of fools,

I sing to thee of apes,

I sing to thee of idiots,

I sing to thee of knaves-

Managers of the Barbecue.

Meat was stale, order not kept;

Roughs were bosses, chiefs and all,

And the only calves and pigs,

Also sheep who were to be there,

Were low-legged, in shoes and shirts.

Lets no more of all this nonsense;

No more sad and sick'ning scenes,

No more beef, fat beef, wasted,

No more speeches from our Duggy,

No more cursed Barbecues. ${ }^{81}$ 
Harper's Weekly gave this report: "A great Douglas ratification meeting was held at Jones Wood, New York, on September 12, and speeches made by Stephen A. Douglas, Herschel V. Johnson, and others. It is said that 40,000 people were present. . . . Senator Douglas has gone to the Springs, being worn out by his labors." 82 As the nominee of the Democratic party, Douglas was involved in a four-way race for the presidency - against Lincoln and two advocates of Secession, John Bell and John Breckinridge. In his New York speech, Douglas "lashed out against any effort to unite with the party of disunionists and traitors to law and the Constitution. He protested that under no circumstances would he endorse a compact so devoid of rectitude." ${ }^{83}$ In this case, it is not so much the policies of the "Little Giant" that are being gored or the styles of Whitman or Longfellow, but the chaos attendant on turning a political event into an "immense barbecue."

On November 10, 1860, Vanity Fair ran a comic paragraph in which it suggested sending boatloads of notable Americans-including P. T. Barnum, President-elect Lincoln, and the Editor of the Herald, James Gordon Bennett-off to a stream in England thought to have rejuvenating properties, producing a bright glow in all those who drink from its waters. The only complication is that the waters contain high concentrations of arsenic. The reference is to a piece that had appeared in Chambers' Edinburgh fournal and which was reprinted in Littels' Living Age reporting on effects on the population of the village of Whitbeck in West Cumberland of ingesting arsenic. Surprisingly, a report in the Pharmaceutical fournal had attributed the "old age which a large portion of the population attain" to their habit of drinking "the arsenic in the water." 84 Vanity Fair had no trouble identifying Americans who would benefit from traveling to the village of Whitbeck where the waters are to be found. And who would be the poet to proclaim the health benefits of drinking the water? None other than Walt Whitman, although even he "could hardly catalogue the probable delights of it. Elfland, Elysium, Lalla Rookh, ducks and green peas, Madeline the battle, Shrewsbury oysters, you, whoever you are, ourselves - all upon the half-shell, would be nothing to it." Yes, "Whitman, indeed, should be the bard of Whitbeck, the newly published fountain of perpetual delight. Let us hope that he will indulge us with a hymn to the arsenicated Undine of the rejuvenating river; or with an epigraph upon the Palingenesy, as illustrated in the history of Whitbeck on the Half-Shell." 85 There is no evidence that he took the advice.

The next week, on November 17, 1860, the periodical began an essay, "J.B.," by directly telling its "Friend reader-your Uncle has a lot of trouble in these receding, seceding, bleeding, up a tree-ding times." Among its own troubles, Vanity Fair complained that "We are going to lose James." How could the periodical survive without one of its favorite objects of satire, James Buchanan, its model do-nothing president? 
"We are out of Ossian, and Adah Issacs Menken \&c. has wailing enough to do for herself in poetry, while Walt Whitman is engaged, or else the world should see a lyric of despair which would drive to raving lunacy the infant in the cradle, and the crow on the housetop. Our stupendous sorrow in such hands would require the Lyre of Chaos for accompaniment and nothin' shorter. We are Positive-nothin' shorter would do." Did Vanity Fair have something specific in mind in saying that "Whitman is engaged"? ${ }^{86}$

On December 1, 1860, Vanity Fair mentioned Whitman in reference to a disputed statue of Washington, which, it had been decided, would be removed from City Hall Park to Tompkins Square. So bad is the sculpture, it charged, that many citizens owe their nervous complaints to having to pass it daily. Once the sculpture finally is removed to its new location, Vanity Fair wrote, “we may 'celebrate ourselves,' as Whitman says; only let us not be too riotous on the occasion, but act as becomes a moral and religious people. In view of the coming winter, we would suggest to the proper authorities that it might be well to cover up the objectionable petrifaction, when removed, with some thick mattingwhich might be allowed to remain on when the winter is past, also, in view of the coming summer." 87

Only two weeks later, on December 15, 1860, Vanity Fair published the comic "The Aesthetics of Boots," by Aldi Phorniosticus, an article I previously discussed. ${ }^{88}$ The second installment of this satire on Transcendentalism, which appeared on January 12, 1861, also refers knowledgeably to Whitman. ${ }^{89}$ Other discussions of Whitman in the first half of 1861 were brief. It was on March 9, 1861, that Vanity Fair asked "The Great Literary Question of the Day," which, as we have seen, was "What will Walt Whitman's Leaves of Grass be when they are dried, and posterity has raked 'em-Hey?"90 The next month, under the title "The Cab-Age," it commented on a bill being considered in Albany to regulate $\mathrm{cab}$ fares in the city. It was an idea the periodical approved, but there remained questions about the best way to charge passengers, by the mile or by establishing a set price for trips within certain zones. As an expert on meters, the poet must be consulted: "Will Walt Whitman, who is said to understand long measures, favor the public with his valuable opinion?"91

Hostilities broke out on April 12, 1861, with the firing on Fort Sumpter. On June 29, 1861, under the title "A Short 'Loaf," Vanity Fair reported that "Captain Baker, the pirate commander of the privateer 'Savannah,' seems to have had quite a select library on board his craft. But he didn't have Walt Whitman's 'Leaves of Grass,' although from the nature (and result) of his cruise, it would appear he intended to 'loaf' (on the high seas) 'and invite his soul' (to a speedy flight-wards). It has, however, turned out a very unprofitable Loaf to this Baker we opine. Hardly 'half a loaf,' in fact." The reference is to the capture on 
June 5, 1861, of the Savannah, commanded by T. Harrison Baker, by the U.S.S. Minnesota. ${ }^{92}$

Following the attack on Fort Sumpter, Charles Leland published a stirring editorial, "Gone-for Good," welcoming the opportunity for America at last to uproot slavery from the nation: "And it is a great privilege for every man of brave heart and noble feelings, to realize that he has the chance to fight in behalf of this truth, more clearly expressed than it has at any time. There is not a principle of progress, of humanity, of liberty, and above all, not a struggle for that holiest of doctrines, free thought and action, which is not involved on the one side-not a dark dogma to the contrary which is not professed by the other. So go on, soldiers of all that it is great and good. . . . The world's last great struggle is before you-happy those who can die in it!" From the perspective of Stephens and Thompson, who paid the bills, Leland went too far in defining the contest in such moral terms, as a struggle to liberate the slaves. He spoke of slavery as "that old primaeval Serpent of the Sum of all Sin-the principle that a vast mass of men should be Mud-Sills. . . . Only in Cotton-dom does its President shamelessly proclaim, that henceforth slavery, and with it of course, aristocracy, shall be enforced as fundamental principles. He who strikes such a land a blow does God good service. $" 93$ The title of the editorial might just as well have applied to Leland's service on Vanity Fair. Soon he too would be "Gone-for Good," his place assumed by Atremus Ward-who in turn would be succeeded by Charles Dawson Shanly early the next year. Vanity Fair would support the prosecution of the war but it continued to resist efforts made on behalf of the Negro.

\section{Humor in a Time of War?}

What is the purpose of any comic periodical in a time of war? What was there to laugh about? What was the point of humor? As Don Seitz points out, "The war absorbed popular attention. A comic paper to succeed must belong to the opposition. Adulation and political supporting have no place in its vital system. In such a time opposition could not thrive." 94 The weekly supported the war as a means of preserving the Union, but went out of its way to insist that the purpose of the conflict was not to liberate an oppressed and worthy race. Its regular cartoons, jokes, and other comments slandering the Negro elicited strong opposition from within the Abolitionist community. In the preface to the sixth volume in July 1862, the editors themselves reported that they had received "several bushels of anonymous letters, expressing the most exaggerated hatred, intensified abhorrence, and unmitigated malevolence toward us. ... Nearly all of the communications received by us on the subject in question, appear to emanate from persons connected with the so-called 'abolition press,' from the fact of their being more or less 
unintelligible to persons actuated merely by principles of common sense." The editors defined their political position by asserting first that "The Nation is, at present, of more consequence than the Negro: that the glory of the former should be considered in preference to the glorification of the latter, and that all the gammon preached about immediate emancipation is a dodge for bringing political capital to the miners of the black-diamond." It then accused the "so-called 'abolition' journals" with being "traitors to their country and abettors of treason, their energies being very generally directed to the purpose of tripping up President Lincoln, by digging trap-holes in the field over which he and his Right-hand Man are steadily advancing to victory." 95 The editor of one of those abolition journals, The Continental Monthly, was none other than their former associate, Charles Godfrey Leland. This was hardly the environment for the gentle humor that the weekly had promised in its first issue.

I have discovered no references to Whitman during the second half of 1861, but there are four in the first half of 1862. On February 15, 1862, in "Wanted-A Poet," Vanity Fair, writing satirically on bits of poetry that the New York Herald used to spice up its obituaries, provided some samples of its own. After a few lines in the pre-Raphaelite mode, it introduced its next quotation by remarking that "the reader cannot fail to recognize the peculiar versification and melody of that great innovator of modern poetry, Walt Whitman. Are we wrong in laying this tender topaz, this pathetic pearl at the door of the distinguished?"

A gem of human form is gone to the realms of grace,

A princely pearl to enrich the kingdom of God's selected race.

$\mathrm{Oh}$, Araminta dear, she is no longer here to solace the lonely hours of father and mother, dear devoted ones of thy world's latest ends.

She, blessed of the three, no longer waits the caressing of parents' anxious care. She, she is there with God's selected gems. ${ }^{96}$

In answer to the above question, my answer is a decided "yes." Of all the parodies of Whitman in Vanity Fair, this strikes me as the least successful.

On April 22, 1862, the magazine published a full-scale parody, under the title "Bath Oriental," one which is much more successful than the obituary verse in capturing the poet's style:

1. Oh a mixed community of persons! O Manahattanese!

Sauntering on Broadway, or loafing out beyond the ferries, here are unwholesome faces.

The lamentable face of the money-broker - the man whose victuals don't seem to agree with each other, neither with him except he speculates well.

The face of the down-town merchant, who has passed several suffering nights disturbed by the agonizing cries of the shapeless child. 
The smug, dew-lapped faces of the tragedians, irresistably funny; and of the komedians, who act as if they heard some very bad news

The doughy faces of infants, the flabby faces of Pater and mater Familias.

The dyspeptic faces from Konnecticut, the shaved, blanched faces of Brooklyn ministers and Academy directors.

The faces of men and women other than dyspeptic, the faces that are innocent-of soap.

The face of the brutish Koboo called the Common Councilman, and of the in lably dirty Kelt.

The thick-lipped mugs of the venerable and harmless men of Ethiopia.

Is there anything worse than a whole community with bodies apparently subject to Hackley, Hope and Haws, city contractors for insuring dirt?

2. Ripsnortez! Ripsnortez!

I swear I go the whole ticket for those who are introducing us to the Turkish Bath.

You, Moslem men and women who came hither from Konstantinople to teach us to be clean, how are you?

I see the lithe-fingered tellaks, I count the profits from the Kahve to be attached to the establishment.

Profits from the buffets of the ladies' department.

Profits from the buffets bestowed upon my body by the swarthy eyed tellaks in the shampoo.

I see Mahomet is going to be our profit.

I see you, you Directors of the Turkish Bath Company. I don't see anybody else, except the Secretary and the General Manager, perhaps.

3. Take off your duds, and I will mine, and we will go for a righteous wash.

We will take sixty baths, including the process of shampooing, at one dollar.

Or one hundred baths, dispensing with the services of the tellaks, at fifty cents.

I swear I will not shirk any part of the process.

The peculiar substance which closes up the pores of the skin cannot be removed by simple immersion in soap and water, but here there is no stoppage and never can be stoppage.

Large and melodious thoughts descend upon me with the slender, spasmic jets of the tepid, blue-white water.

I see the butter-colored chips flying off in great flakes and slivers.

By Jingo! they are like little rolls of human vermicelli.

Dulcemente! Dulcemente!

I swear I don't know whether I am standing on my head or heels. My feet strike a tangent of a segment of the apres-midi rainbow.

I wait unseen and always, and snooze through the lethargic mist.

I experience the manipulation of the expert tellaks. Only themselves understand themselves and the like of themselves.

Punching with balsamic blows the anatomy of the human frame; the deltoid and the latissimus dorsi, and the miceps buscle.

But I walk or sit indifferent-I am satisfied. I am as one disembodied, triumphant.

I confer with spirits equally with me washed. They invite me to partake of a little spirits-and-water with them in the Kahve attached to the establishment.

4. I see no longer the lamentable faces.

The faces like those of the most blear-eyed and daddering idiots they have at 
the Asylum.

Nor the dyspeptic faces, nor the face of the incalculably dirty Kelt.

(What have I to do with lamentation?)

I would see this Moslem institution established not only in the Manahatta, but in every city of These States, inland and seabord.

With edifices, and rules, and trustees, and other strict arguments.

Financially considered, there can be no question that it will be a profitable investment.

Celebrate with me, $\mathrm{O}$ enfans prepared for the Turkish Bath! ${ }^{97}$

Is the parody by Whitman himself? It demonstrates a remarkable knowledge of the poet's style. There are precise references to what would become Section 44 of "Song of Myself" and "Salut Au Monde!" Further, the parody hearkens back to Whitman's editorial days in calling upon the New York authorities to make provision for public bathing houses. In a leader entitled "Cheap Baths-Health and Beauty" for the New York Sun on March 30, 1843, he had spoken of the "wholesomeness of frequent ablutions of the body." He charged that the American bathing habits - or lack thereof - were a national disgrace and so urged the "municipal fathers" to establish "free baths." 98 Now, however, the poet looks upon the establishment of Turkish baths as a sound private investment.

Vanity Fair published "Interviews with Our Aggrieved Subjects" on May 10, 1862. Three complaints are considered: those of Mr. W. C. Bryant's Duck, that of a city Judge, McCunn, and first and foremost, its old friend, Henry Ward Beecher, an "eccentric but versatile divine." Beecher arrived at the editorial offices to complain that a recent portrait of him (see Figure 2) had done him a great disservice. Not only was his "neck too thick, his legs too short, and his hair too long," but even worse, "his family and congregation were greatly dissatisfied with the shirt-

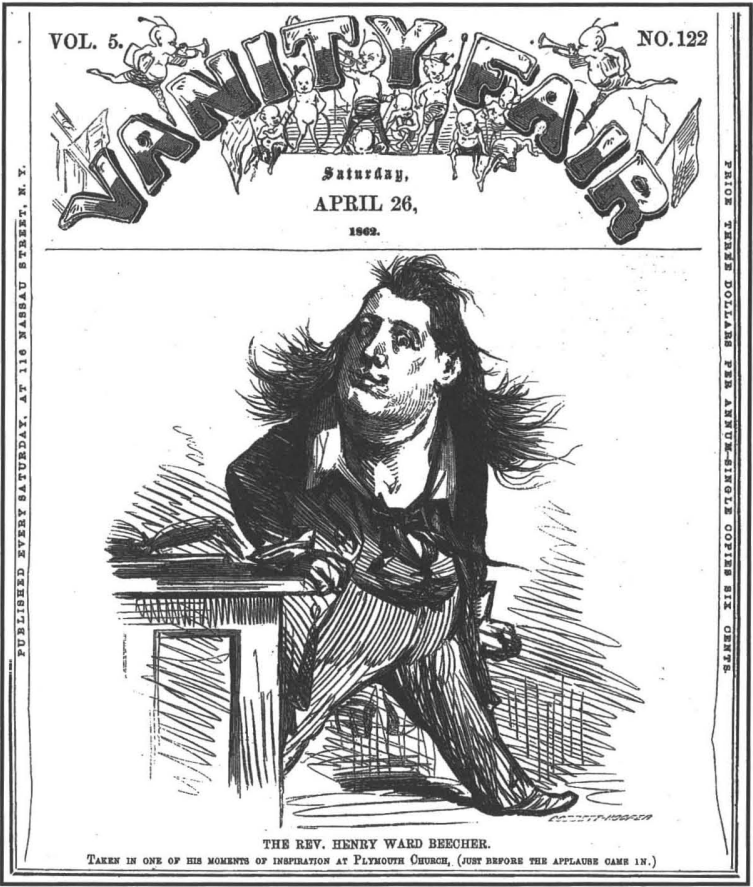

Figure 2 
collar we had attributed to him, which had given a rise to a rumor in Brooklyn that he is in the habit of borrowing his linen from Mr. Walter Whitman, the originator of the grass school of poetry." The editors proved to be men of compassion: "Seeing that our Rev. visitor was really hurt by the shirt-collar, we promised to mend it at some future opportunity, upon which he took leave of us in tolerably good spirits." 99 If only all conflicts could be resolved so easily.

The last of the references to Whitman that I have discovered occurred the next week, May 17, 1862. Commencement time was approaching. Since the graduates-to-be were in need of subjects for their final orations, Vanity Fair offered its assistance by listing twelve promising subjects under the heading "To Young Gentlemen who are preparing for Commencement Day." Number III refers to Whitman: "For a Philosophical Oration. The Stuck-Eichen-Dummer-Junger-Kleinbocker of Immanuel Kant in its Influence on Walt Whitman." Other topics include "IV. For a Mathematical Oration. The Calculus of Army-Contracts as Involving an Unknown Quantity of Profit" and "VIII. For a Poem. The Loves of the Editors." Whether any youth took up these suggestions in 1862 or subsequently is unknown. ${ }^{100}$

Just a few months later, on September 20, 1862, Vanity Fair published a poem, "V. F. to the Rescue," that conveys its own sense of the irrelevance of humor in a time of national crisis. The weekly is willing to put aside its comic role in order to rally public support for the overriding cause: saving the Union.

Cast, for a moment's space aside,

Lie there, our bauble, caps and bells:

The North's on Northern soil defied,

And on the border's Union side

Rebellion whoops and yells.

The Jester-fired with patriot zeal-

Waives, for the nonce, his gibes and quips;

Up from his heart a stern appeal-

A slogan for the common weal-

Is surging to his lips.

Rescue! the Flag of Stars is torn;

Think! if it perish where are we?

Benighted; beaconless, forlorn,

Wrecked, and of every anchor shorn,

We drift with anarchy!

Rescue! since sacred starlight led

The shepherd seers to Bethlehem's vale,

No orbs that glitter overhead

So grand a light as ours have shed:

Say, brothers, shall they pale? 
Rescue! let faction's voice be mute,

March all! in solid column march;

Have ye not heard that Treason's foot,

Spurning the Union, doth pollute

The keystone of its arch?

Rescue! let jealousy no more

Disturb our counsels, mar our plans;

Strike all, as struck your sires of yore;

What they bequeathed do you restore:

Strike for God's cause and man's! ${ }^{101}$

As I have mentioned, the rising costs of paper and other expenses during the war took a heavy toll on this and all periodicals. On December 27, 1862, William A. Stephens announced that with the new year Vanity Fair would become a monthly. After only two monthly issues it ceased publication, except for a run of ten weekly issues beginning in May of that year. ${ }^{102}$

For two and one half years Walt Whitman figured prominently on the pages of Vanity Fair. During 1861, when, apparently, there were no references to Whitman in the press, Vanity Fair helped keep his name alive. The writers for Vanity Fair demonstrate a remarkable knowledge of Whitman's work - as we might expect from his close friends and supporters from Pfaff's. Further, in Vanity Fair these writers found a vehicle to express their own free and open sensibility-they could joke about sexuality and make fun of the pious religious press. To understand Whitman's presence in the magazine is to see that in 1860 he had found a congenial and supportive community of professional writers who understood the magnitude of his achievement and did their best to promote him. They wanted to make sure that his Leaves would continue to be read long after he and they were dead and buried-even at the risk of sending overly sensitive younger readers to the insane asylum.

College of William and Mary

\section{NOTES}

1 Vanity Fair 3 (March 9, 1861), 118.

2 Vanity Fair 2 (September 15, 1860), 146. I have silently corrected a typographical error. Vanity Fair had given the name as Isaac Adah Menkens.

3 Gay Wilson Allen, The Solitary Singer (New York: New York University Press, 1967), 262. 
4 Scott Giantvalley, Walt Whitman: A Reference Guide (Boston: G. K. Hall, 1981). All mentions of Whitman are listed in an appendix.

5 Frank Luther Mott, A History of American Magazines: 1850-1865 (Cambridge: Harvard University Press, 1967), 2:520.

6 Vanity Fair 5 (May 10, 1862), 232.

7 “The Aesthetics of Boots," Vanity Fair 2 (December 15, 1860), 299.

8 Saturday Press (December 24, 1859).

9 "The Aesthetics of Boots, Part II," Vanity Fair 3 (January 12, 1861), 23. The reference apparently is to "All about a Mocking Bird," in the Saturday Press (January 7, 1860 ), 3. The author speaks of Whitman's music carrying with it "all the subtle analogies of our own associations."

10 Charles I. Glicksberg, "Charles Godfrey Leland and Vanity Fair," Pennsylvania Magazine of History and Biography 62 (July 1938), 309.

11 Frank Luther Mott, A History of American Magazines, 2:520.

12 Harper's Weekly 4 (February 4, 1860), 78.

13 Vanity Fair 1 (December 31, 1859), iv; 13.

14 Don C. Seitz, Artemus Ward (Charles Farrar Browne) (New York: Harper, 1919), 79-80.

15 Vanity Fair 1 (March 17, 1860), 183.

16 Charles Godfrey Leland, Memoirs (London: William Heineman, 1893), 1:22.

17 Glicksburg, 323.

18 Seitz, 84 .

19 Leland, 1:22.

20 James C. Austin, Artemus Ward (Boston: Twayne 1964), 44.

21 North American Review 102 (April 1866), 590. In comparing Vanity Fair to Punch, the North American remarks, "There were the same central cartoons, the satirical pictures of society on just the same pages, and the puns and conundrums on the same corner. Such copying suggested comparison; and, though this paper was called the Punch of America, it seemed one of those foreign editions of greatness that are always suspicious. . . . It flourished, or appeared to, for a time, then faded with the political party to which it was addressed, and both went simultaneously to a common tomb. The difficulties of the case were, no doubt, aggravated by the high cost of publication during the war" (590).

22 David S. Reynolds, Walt Whitman's America: A Cultural Biography (New York: Knopf, 1995), 377-378.

23 Ferris Greenslet, Thomas Bailey Aldrich (Boston: Houghton Mifflin, 1908), 45.

24 Laura Stedman and George. M. Gould, eds., The Life and Letters of Edmund Clarence Stedman (New York, Moffat, Yard \& C., 1910), 1:208.

25 Harper's Weekly 6 (April 26, 1862), 267, published an extensive obituary notice with an analysis of O'Brien's contributions to American letters and courageous service as a Union soldier. 
26 Seitz includes a fine discussion of Pfaff's in his Artemus Ward.

27 Vanity Fair 1 (December 31, 1861), 12.

28 Stedman and Gould, Life and Letters, 1:209.

29 Seitz, 99.

30 Christine Stansell, "Whitman at Pfaff's: Commercial Culture, Literary Life and New York Bohemia at Mid-Century," Walt Whitman Quarterly Review 10 (Winter 1993), 121.

31 Charley Shively, "Vaughan, Frederick B.," Walt Whitman: An Encyclopedia, ed. J.

R. LeMaster and Donald D. Kummings (New York: Gale, 1998), 753-754.

32 Stansell, "Whitman at Pfaff's," 107-126.

33 Sculley Bradley and Harold Blodgett, eds., 660-661. Leaves of Grass: Norton Critical Edition (New York: W.W. Norton, 1973), 660-661.

34 Leaves of Grass, 131, 125.

35 Vanity Fair 1 (December 31, 1859), 12.

36 Glicksberg, 319-320.

37 Vanity Fair 2 (August 4, 1860), 65.

38 Vanity Fair 1 (April 14, 1860), 243.

39 Vanity Fair 1 (December 31, 1859), 12.

40 Horace Traubel, $W W C, 2: 53$.

41 Floyd Stovall, The Long Foreground of Leaves of Grass (Charlottesville: University Press of Virginia, 1974), 146.

42 Edwin Haviland Miller, ed., The Correspondence (New York: New York University Press, 1961), 1:55. Letter dated June 12, 1860. The items included a parody, "Enfans de Soixante-Seize" and a review.

43 Quoted from Leland's journal by Elizabeth Robins Pennell, Charles Godfrey Leland: a Biography (Boston: Houghton, Mifflin, 1906), 2:111. Quoted by Stovall, 224-225.

44 Leland, Memoirs, 226. Quoted in Stovall, 225.

45 National Cyclopedia of American Biography (New York, 1898), 1:255.

46 Glicksberg, 315.

47 Allen's Solitary Singer provides a full description of these events, 236-244.

$48 W W C 1,236-237$.

49 Vanity Fair 1 (March 10, 1860), 172.

50 Joseph Jay Rubin, The Historic Whitman (University Park: The Pennsylvania State University Press, 1973), 306.

51 Bert Hansen, “American Physicians' Discovery of Homosexuals, 1880-1900: A New Diagnosis in a Changing Society," in Judith Walzer Leavitt and Ronald L. Numbers, eds., Sickness and Health in America (Madison: University of Wisconsin Press, 1997), 16, and note 14, 28. Hansen's essay appeared originally in Charles E. Rosenberg and Janet Golden, Framing Disease: Studies in Cultural History (New Brunswick: Rutgers 
University Press 1992), 134-154.

52 Shively, 753-754.

53 Vanity Fair 1 (March 17, 1860), 183.

54 Leaves of Grass, 52.

55 Hansen, 17.

56 Justin Kaplan, Walt Whitman: A Life (New York: Simon and Schuster, 1980), 246.

57 Harper's Weekly 4 (March 16, 1860), 162.

58 Vanity Fair 1 (April 14, 1860), 243.

59 Vanity Fair 1 (April 14, 1860), 251.

60 Whitman: Poetry and Prose (New York: Library of America, 1996), 87.

61 "Walt Whitman: Leaves of Grass," Saturday Press (May 19, 1860), 2.

62 Vanity Fair 1 (May 19, 1860), 326.

63 Leland, 19-20.

64 Glicksberg, 317.

65 Stedman and Gould, 1:217-218. In a letter to his mother dated October 19, 1860, Stedman claimed that the notoriety of the poem was crucial to the survival of Vanity Fair itself: "They are making great sales and say I have saved the paper. Lowell has written on and offered to contribute, and a brilliant staff will be at once announced" (218). For the two-part poem, which appeared on October 13 and October 20, Stedman received $\$ 50$ and the plates.

66 Vanity Fair 2 (November 10, 1860), 231-232.

67 Vanity Fair 2 (July 7, 1860), 23.

68 James Wynne, Private Libraries of New York (New York: E. French, 1860). The book is described as follows: "Prepared for and published in the Evening post, about two years since .... The separate articles have all undergone a careful revision, while many have been entirely rewritten, and a few new ones added."

69 Vanity Fair 2 (August 4, 1860), 69.

70 Alexander von Humboldt, Cosmos (New York: Harper and Brothers, 1860).

71 Charles Paul de Kock, Le Cocu (Paris: J. Rouff et cie.: 1831).

72 Elizabeth Oaks Smith, The Sinless Child and Other Poems (New York: Wiley and Putnam, 1843).

73 Vanity Fair 2 (September 22, 1860), 155.

74 Vanity Fair 2 (August 11, 1860), 73.

75 Reynolds, "Whitman and Popular Culture," 535.

76 Sam Worley, "Popular Influences on Whitman," Walt Whitman: An Encyclopedia, 312.

77 Vanity Fair 2 (September 15, 1860), 146. 
78 Leaves of Grass: Facsimile of the 1856 Edition, ed. Gay Wilson Allen (Norwood Editions, 1976), 256.

79 The Poems of Henry Wadsworth Longfellow (New York: The Modern Library, 1944), 187; Leaves of Grass, 242-246.

80 "Douglas and Fusion," New York Times (September 13, 1860), 4.

81 Vanity Fair 2 (September 29, 1860), 168-169.

82 Harper's Weekly (September 22, 1860): 598-599.

83 Robert W. Johnson, Stephen A. Douglas (New York: Oxford University Press 1973), 793.

84 Little's Living Age 71 (October 5, 1860), 31-34.

85 Vanity Fair 2 (November 10, 1860), 235.

86 Vanity Fair 2 (November 17, 1860), 252.

87 Vanity Fair 2 (December 1, 1860), 278.

88 Vanity Fair 2 (December 15, 1860), 299.

89 Vanity Fair 3 (January 12, 1861), 23.

90 Vanity Fair 3 (March 9, 1861), 118.

91 Vanity Fair 3 (April 13, 1861), 179.

92 Vanity Fair 3 (June 29, 1861), 297.

93 Vanity Fair 3 (April 20, 1861), 198.

94 Seitz, 88-89.

95 Vanity Fair 6 (July 5, 1862), 3

96 Vanity Fair 5 (February 15, 1862), 87.

97 Vanity Fair 5 (April 12, 1862), 183.

98 Walt Whitman, The fournalism, ed. Herbert Bergman (New York: Peter Lang, 1998), 1:172-173.

99 Vanity Fair 5 (May 10, 1862), 232.

100 Vanity Fair 6 (September 20, 1862 ), 137.

101 Vanity Fair 6 (December 27, 1862), end page. 


\section{APPENDIX I}

References to Walt Whitman in Vanity Fair

$\underline{1860}$

*ANON. "Ages of American Authors."

Vanity Fair 1 (March 10, 1860), 172.

*ANON. “Counter-Jumps. A

Poemettina.-AfterWalt Whitman."

Vanity Fair 1 (March 17, 1860), 183.

*ANON. "A True 'Barbaric Yawp."”

Vanity Fair 1 (April 14, 1860), 251.

*ANON. "The Model Statesman."

Vanity Fair 1 (April 14, 1860), 243.

ANON. "Our Agricultural Column:

Calamus." Vanity Fair 1 (May 19, 1860), 326.

*ANON. "The Torch-Bearer. A Paean for the Fourth of July. (After Walt Whitman.)" Vanity Fair 2 (July 7, 1860), 23.

ANON. "Private Libraries of New York." Vanity Fair 2 (August 4, 1860), 69.

ANON. "The Telegraph Tour of

Broadway Spuytentuyfel." Vanity Fair 2 (August 11, 1860), 73.

ANON. "Curious if True." Vanity Fair 2 (September 15, 1860), 146.

*ANON. "The Song of the Barbecue.

Not by Walt Whitman, nor Professor Longfellow." Vanity Fair 2

(September 29, 1860), 168-169.

ANON. "Whitbeck on the Half-Shell."

Vanity Fair 2 (November 10, 1860), 235.

*ANON. "Incidental mention."

Vanity Fair 2 (November 17, 1860), 252.
ANON. "J. B." Vanity Fair 2 (November 17, 1860), 252.

ANON. “A Happy Removal.” Vanity Fair

2 (December 1, 1860), 278.

ANON. "The Aesthetics of Boots."

Vanity Fair 2 (December 15, 1860), 299.

1861

ANON. "The Aesthetics of Boots: Part II." Vanity Fair 3 (January 12, 1861), 23-24.

ANON. "The Great Literary Question of the Day." Vanity Fair 3 (March 9, 1861), 118.

ANON. "The Cab-Age." Vanity Fair 3 (April 13, 1861), 179.

ANON. "A Short 'Loaf." Vanity Fair 3 (June 29, 1861), 297.

$\underline{1862}$

ANON. "Wanted-A Poet." Vanity Fair 5 (February 15, 1862), 87.

*[Whitman, Walt?] "Bath Oriental." Vanity Fair 5 (April 12, 1862), 183.

ANON. "Interviews With Our Aggrieved Subjects." Vanity Fair 5 (May 10, 1862), 232.

ANON. "ToYoung Gentlemen Who Are Preparing For Commencement Day." Vanity Fair 5 (May 17, 1862), 242.

* Denotes previously cited article. 